\title{
PENGARUH LAYANAN BIMBINGAN KELOMPOK DENGAN TEKNIK SYMBOLIC MODELLING TERHADAP MOTIVASI BELAJAR SISWA KELAS XI SMA NEGERI 5 SEMARANG
}

\section{The Effect Of Group Counseling Services With Symbolic Modeling Techniques On The Learning Motivation Of Grade XI Students Of SMAN 5 Semarang}

\author{
Oleh: Innesia Puspita Dewi*, Supardi**, dan Gregorius Rahastono Ajie**** \\ e-mail: inessiapuspitadewi719@gmail.com
}

\begin{abstract}
ABSTRAK
Penelitian ini dilatarbelakangi oleh rendahnya motivasi belajar pada siswa kelas XI SMA Negeri 5 Semarang yang ditandai dengan siswa sering keluar masuk kelas saat jam pelajaran, menunda-nunda tugas, asik bermain gadget, asik mengobrol dengan teman ketika jam pelajaran berlangsung, dan sering melamun saat diterangkan materi pelajaran. Permasalahan yang diangkat dari penelitian ini adalah seberapa besar tingkat motivasi belajar siswa kelas XI SMA Negeri 5 Semarang sesudah diberikan layanan bimbingan kelompok dan bagaimana pengaruh layanan bimbingan kelompok dengan teknik symbolic modelling terhadap motivasi belajar siswa kelas XI SMA Negeri 5 Semarang. Tujuan penelitian ini adalah untuk mengetahui pengaruh layanan bimbingan kelompok dengan teknik symbolic modelling terhadap motivasi belajar siswa kelas XI SMA Negeri 5 Semarang. Sampel yang diambil sebanyak 20 siswa, 10 siswa untuk kelompok eksperimen dan 10 siswa untuk kelompok kontrol dengan sample random sampling yaitu teknik penentuan sampel dari populasi dilakukan secara acak tanpa memperhatikan strata yang ada dalam populasi itu. Treatment dilaksanakan sebanyak lima kali pada sampel. Hasil uji hipotesis diperoleh $t_{\text {hitung }}$ sebesar 2,645 dengan $t_{\text {tabel }}$ taraf signifikansi 5\% yaitu 2,101. Hal tersebut menunjukkan bahwa $t_{\text {hitung }} 2,645>t_{\text {tabel }} 2,101$. Dengan demikian dapat ditarik kesimpulan bahwa ada pengaruh layanan bimbingan kelompok teknik symbolic modelling terhadap motivasi belajar siswa kelas XI SMA Negeri 5 Semarang.
\end{abstract}

\section{Kata Kunci : Layanan Bimbingan Kelompok, Teknik Symbolic Modelling, Motivasi Belajar Siswa.}

\section{ABSTRACT}

This research is motivated by the low motivation to learn in grade XI students of SMA Negeri 5 Semarang, which is characterized by students often entering and leaving the classroom during class time, delaying assignments, cool playing gadgets, cool chatting with friends during class time, and often daydreaming when explained subject matter. The problem raised from this research is how much the level of student motivation in grade XI SMA Negeri 5 Semarang after being given group guidance services and how the influence of group guidance services with symbolic modeling techniques on student motivation in grade XI SMA Negeri 5 Semarang. The purpose of this study was to determine the effect of group guidance services with symbolic modeling techniques on student motivation in grade XI of SMA Negeri 5 Semarang. Samples taken as many as 20 students, 10 students for the experimental group and 10 students for the control group with a random sample sampling technique that is the determination of samples from the population carried out randomly

Puspita Dewi ${ }^{1}$, Supardi ${ }^{2}$, dan Gregorius Rahastono Ajie ${ }^{3}$

Bimbingan dan Konseling

Universitas PGRI Semarang 
without regard to strata in that population. Treatment was carried out five times in the sample. Hypothesis test results obtained tcount of 2.645 with a $5 \%$ significance level table that is 2.101. This shows that tcount 2,645> ttable 2,101. Thus it can be concluded that there is an influence of symbolic modeling group guidance services on the learning motivation of grade XI students of SMA Negeri 5 Semarang.

Keyword : Group Guidance Services, Symbolic Modeling Techniques, Student Learning Motivation. 


\section{PENDAHULUAN}

Aktivitas belajar bukanlah suatu kegiatan yang dilakukan yang terlepas dari faktor lain. Aktivitas belajar merupakan kegiatan yang melibatkan unsur jiwa dan raga. Faktor yang mempengaruhi aktivitas belajar antara lain adalah motivasi. Kurangnya motivasi belajar pada siswa akan menimbulkan berbagai macam masalah dalam tugas perkembangan pada proses belajarnya, seperti siswa malas untuk mengerjakan PR, malas untuk memperhatikan gurunya ketika menerangkan materi. Hal tersebut dapat menghambat siswa dalam proses kegiatan belajar mengajar. Oleh karena itu perlunya menanamkan sikap motivasi pada siswa sangatlah penting agar siswa mampu melalui tugas perkembangannya yang harus dilalui dalam proses kegiatan belajar mengajar. Motivasi adalah gejala psikologis dalam bentuk dorongan yang timbul pada diri seseorang sadar atau tidak sadar untuk melakukan suatu tindakan dengan tujuan tertentu (Djamarah, 2015: 152).

Motivasi belajar memberikan pengaruh terhadap aktivitas siswa untuk menjalankan kegiatan dalam hal pendidikan. Motivasi mendorong manusia untuk berbuat dengan kata lain sebagai motor penggerak dari setiap kegiatan yang akan dikerjakan (Sardiman dalam Maulida, 2012: 76). Menggerakkan motivasi belajar dapat mendorong pencapaian prestasi belajar secara optimal. Walaupun siswa mempunyai bakat dan minat yang tinggi tetapi bila tidak disertai dengan motivasi belajar maka prestasi belajar tidak optimal begitu juga sebaliknya. Bisa juga siswa yang mempunyai intelegensi tinggi boleh jadi gagal karena kekurangan motivasi. Sehingga motivasi mempunyai peranan penting dalam kegiatan belajar karena motivasi adalah tenaga yang menggerakkan dan mengarahkan seseorang.

Berdasarkan hasil wawancara dengan Guru Mapel dan Guru BK SMA N 5 Semarang pada tanggal 28 Maret 2019, menyatakan permasalahan yang sedang dialami pada siswa kelas XI berkaitan dengan kesulitan dalam menumbuhkan semangat belajar, hal ini ditandai dengan : siswa sering keluar masuk kelas ketika jam pelajaran, terlambat masuk sekolah/kelas, menunda-nunda tugas, asik bermain gadget, asik mengobrol dengan teman ketika guru mapel menerangkan materi pelajaran, sering melamun saat diterangkan materi pelajaran. Serta hasil wawancara dengan 3 siswa dengan diperoleh hasil siswa mengakui merasa malas belajar dan mengantuk ketika belajar, merasa bosan dan malas mendengarkan ketika guru yang tidak disukai menerangkan materi pelajaran, tidak bisa mengatur waktu untuk belajar, untuk bermain, belajar ketika ada ulangan saja.

Menurut Sukardi (2008:64) layanan bimbingan kelompok yaitu layanan bimbingan yang memungkinkan sejumlah peserta didik secara bersama-sama memperoleh berbagai bahan dari narasumber tertentu (terutama dari pembimbing/konselor) yang berguna untuk menunjang kehidupannya sehari-hari baik individu maupun sebagai pelajar.

Menurut Gunawan (dalam Yuniarwati, 2018:02) layanan bimbingan kelompok merupakan sebuah layanan yang diberikan oleh sekelompok individu (8-12 orang) dipimpin oleh pemimpin kelompok yang membahas masalah-masalah umum dengan memanfaatkan dinamika kelompok.

Penggunaan layanan bimbingan kelompok secara khusus bertujuan untuk 
mengembangkan perasaan, pikiran persepsi, wawasan dan sikap seperti berani mengeluarkan pendapat, mampu bertenggang rasa dan menghormati orang lain.

Dari uraian-uraian para ahli diatas dapat disimpulkan bahwa bimbingan kelompok merupakan bantuan terhadap individu yang digunakan dalam situasi kelompok. Bimbingan kelompok dapat berupa penyampaian informasi ataupun aktifitas kelompok membahas masalahmasalah pendidikan, pekerjaan, pribadi dan sosial.

Motivasi belajar merupakan permasalahan yang sering dialami oleh siswa serta merupakan permasalahan yang harus ditangani dengan pihak sekolah. Dalam mengatasi siswa yang memiliki semangat belajarnya rendah bimbingan kelompok berperan penting untuk menangani permasalahan belajar bagi semua siswa yang memiliki permasalahan ataupun tidak. Ada banyak penggunaan teknik dalam bimbingan kelompok yang dapat menyelesaiakan permasalahan sesuai dengan masalahannya. Berdasarkan permasalahan yang dialami oleh siswa kelas XI SMA N 5 Semarang yang berkaitan dengan Motivasi Belajar, untuk menumbuhkan semangat belajar siswa tersebut dapat digunakan berbagai cara yang efektif, salah satunya yaitu dengan teknik symbolic modelling terhadap motivasi belajar siswa.

Menurut Ratna (2013:47) modeling merupakan belajar melalui observasi dengan menambahkan atau mengurangi tingkah laku yang teramati, menggeneralisir berbagai pengamatan sekaligus, melibatkan proses kognitif. Menurut Perry (dalam Yuniarwati 2018:06) mendifinisikan modeling sebagai proses belajar melalui observasi dimana tingkah laku dari seorang individu atau kelompok, sebagai model, berperan sebagai rangsangan bagi pikiran-pikiran, sikapsikap, atau tingkah laku sebagai bagian.

Dalam penelitian ini peneliti tertarik menggunakan teknik symbolic modeling, karena anak usia remaja lebih tertarik dengan dengan film/video. Menurut Ratna (2013:52) modeling simbolis merupakan cara/prosedur yang dilakukan dengan menggunakan media seperti film, video, buku pedoman, dll dengan cara mendemonstrasikan perilaku yang dikehendaki atau hendaknya dimiliki oleh klien.

\section{Motivasi Belajar}

Motivasi juga dikatakan serangkaian usaha untuk menyediakan kondisi-kondisi tertentu, sehingga seseorang mau dan ingin melakukan sesuatu, dan bila ia tidak suka, maka akan berusaha untuk meniadakan atau mengelakkan perasaan tidak suka itu. Jadi motivasi itu dapat dirangsang oleh faktor dari luar tetapi motivasi itu adalah tumbuh di dalam diri seseorang. Dalam kegiatan belajar, motivasi dapat dikatakan sebagai keseluruhan daya penggerak di dalam diri siswa yang menimbulkan kegiatan belajar, yang menjamin kelangsungan dari kegiatan belajar dan yang memberikan arah pada kegiatan belajar, sehingga tujuan yang dikehendaki oleh subjek belajar itu dapat tercapai. Dikatakan "keseluruhan", karena pada umumnya ada beberapa motif yang bersama-sama menggerakkan siswa untuk belajar (Sardiman, 2008:75).

\section{Layanan Bimbingan Kelompok dengan Teknik Symbolic Modelling}

Sukardi (2008:64) menjelaskan bahwa layanan bimbingan kelompok yaitu layanan bimbingan yang memungkinkan sejumlah peserta didik secara bersama-sama memperoleh berbagai bahan dari narasumber tertentu (terutama dari pembimbing/konselor) 
yang berguna untuk menunjang kehidupannya sehari-hari baik individu maupun sebagai pelajar, anggota keluarga dan masyarakat serta untuk pertimbangan dalam pengambilan keputusan.

Erford menjelaskan bahwa modeling adalah proses bagaimana individu belajar dari mengamati orang lain, termasuk salah satu komponen teori belajar sosial yang dikembangkan oleh Albert Bandura. Menurut Taylor, Russ-Eft, dan Chan, hal ini telah menjadi salah satu intervensi pelatihan berbasi psikologi yang paling luas digunakan, paling banyak diteliti dan sangat dihormati (Erford, 2017:340). Symbolic modeling melibatkan mengilustrasikan perilaku target melalui rekaman video atau audio. Modeling simbolik memungkinkan konselor profesional untuk memiliki kontrol yang lebih besar atas keakuratan demonstrasi perilakunya.

\section{METODE PENELITIAN}

Penelitian dengan judul Pengaruh Layanan Bimbingan Kelompok Dengan Teknik Symbolic Modelling Terhadap Motivasi Belajar Siswa Kelas XI SMA Negeri 5 Semarang. Waktu penelitian pada bulan Agustus - September 2019. Dalam penelitian ini proses ekperimen pengumpulan data dapat dibagi menjadi tiga tahap yaitu tahap persiapan, tahap pelaksanaan dan tahap pengakhiran. Dimana setiap tahap tersebut peneliti memuat beberapa langkah-langkah sebagai berikut :

\section{Persiapan}

a. Subyek penelitian yang akan diteliti yaitu siswa kelas XI IPA 1, XI IPA 2, XI IPA 3,XI IPA 4, XI IPA 5, XI IPA 6, XI IPA 7,XI IPA 8,XI IPA 9, XI IPA 10 XI IPS 1, XI IPS 2 dan XI BAHASA 1. Dari jumlah 13 kelas tersebut terpilih 3 kelas menggunakan cluster random sampling. Dalam hal tersebut kelas yang berhasil terpilih adalah kelas XI IPA 7 dan XI IPA 9. Satu kelas untuk try out yaitu kelas XI IPA 10 dan dua kelas yang menjadi kelompok kontrol dan eksperimen, yaitu kelas XI IPA 7 dan XI IPA 9.

b. Melakukan try out skala Motivasi Belajar dikelas XI IPA 10 SMA Negeri 5 Semarang yang berjumlah 33 siswa untuk menguju validitas dan realibilitas.

c. Melakukan pretest terhadap kelas XI IPA 7 dengan jumlah 32 siswa dan XI IPA 9 dengan jumlah 32 siswa. Selanjutnya kelas yang diberi pre-test akan dipilih masing-masing 10 siswa sebagai kelompok control dan kelompok eksperimen dengan menggunakan simple random sampling. Dikatakan simple (sederhana) karena pengambilan anggota sampel dari populasi dilakukan secara acak tanpa memperhatikan strata yang ada dalam populasi itu (Sugiyono, 2015: 120)

d. Berdasarkan data pretest terhadap kelas XI IPA 7 dan XI IPA 9 dengan skala Motivasi Belajar menggunakan rentang skor 1 sampai 4 akan dicari skor tertinggi dan skor terendah.

2. Pelaksanaan Eksperimen

a. Setelah menentukan 10 siswa dari kelas XI IPA 7 dan 10 siswa dari kelas XI IPA 9, selanjutnya adalah menentukan kelompok eksperimen dan kelompok kontrol dari kedua kelas tersebut yang dilakukan secara acak.

b. Setelah pemilihan kelompok eksperimen dan kelompok kontrol 
secara acak tersebut, maka terpilihlah kelas XI IPA 7 sebagai kelompok kontrol dan kelas XI IPA 9 sebagai kelompok eksperimen.

c. Kelompok kontrol diberikan layanan bimbingan kelompok seperti biasa yang dilakukan oleh guru BK sedangkan kelompok eksperimen diberikan layanan bimbingan kelompok dengan menggunakan teknik symbolic modeling oleh peneliti.

d. Treatment dilaksanakan terhadap kelompok eksperimen sebanyak 5 kali sedangkan kelompok kontrol diberikan layanan oleh guru BK/konselor.

3. Akhir Eksperimen

a. Setelah diberikan perlakuan selanjutnya kelompok kontrol dan kelompok eksperimen diberikan posttest guna mengetahui adanya perbedaan antara kelompok kontrol dengan kelompok eksperimen.

b. Selanjutnya peneliti melakukan analisis menggunakan uji-t untuk mengetahui pengaruh layanan bimbingan kelompok dengan teknik symbolic modeling.

\section{HASIL PENELITIAN}

Data deskripsi pre-test dan post-test kelompok eksperimen dengan interval, sebagai berikut :

Kelas interval

$=\frac{\text { Jumlah skor tertinggi-jumlah skor terendah }}{\text { jumlah kategori }}$

$=\frac{(30 \times 4)-(30 \times 1)}{4}$

$=\frac{120-30}{4}$

$=\frac{90}{4}=22,5$ dibulatkan menjadi 22

Berikut adalah distribusi bergolong yang dapat dilihat pada tabel di bawah ini:

Tabel 1 Kategori Distribusi Bergolong

\begin{tabular}{|c|c|c|}
\hline No & Kategori & Interval \\
\hline 1 & Sangat Tinggi & $98-120$ \\
\hline 2 & Tinggi & $75-97$ \\
\hline 3 & Rendah & $52-74$ \\
\hline 4 & $\begin{array}{c}\text { Sangat } \\
\text { Rendah }\end{array}$ & $30-51$ \\
\hline
\end{tabular}

Berikut perbandingan hasil pre-test dan post-test kelompok kontrol dan eksperimen siswa kelas XI SMA Negeri 5 Semarang, sebagai berikut:

Tabel 2 Rekapitulasi Data Pretest dan Posttest Motivasi Belajar Kelompok Kontrol dan Eksperimen

\begin{tabular}{|c|c|c|c|c|c|c|c|c|c|}
\hline \multirow{3}{*}{ No } & \multicolumn{4}{|c|}{ Pretest } & \multirow{3}{*}{ No } & \multicolumn{4}{|c|}{ Pretest } \\
\hline & \multicolumn{2}{|c|}{ Kontrol } & \multicolumn{2}{|c|}{ Eksperimen } & & \multicolumn{2}{|c|}{ Kontrol } & \multicolumn{2}{|c|}{ Eksperimen } \\
\hline & Skor & Ket & Skor & Ket & & Skor & Ket & Skor & Ket \\
\hline 1 & 74 & Rendah & 74 & Rendah & 1 & 80 & Tinggi & 113 & $\begin{array}{l}\text { Sangat } \\
\text { Tinggi }\end{array}$ \\
\hline 2 & 74 & Rendah & 74 & Rendah & 2 & 78 & Tinggi & 96 & Tinggi \\
\hline 3 & 79 & Tinggi & 75 & Tinggi & 3 & 87 & Tinggi & 83 & Tinggi \\
\hline 4 & 81 & Tinggi & 76 & Tinggi & 4 & 86 & Tinggi & 89 & Tinggi \\
\hline 5 & 81 & Tinggi & 79 & Tinggi & 5 & 85 & Tinggi & 91 & Tinggi \\
\hline 6 & 82 & Tinggi & 83 & Tinggi & 6 & 77 & Tinggi & 87 & Tinggi \\
\hline 7 & 83 & Tinggi & 84 & Tinggi & 7 & 84 & Tinggi & 105 & $\begin{array}{l}\text { Sangat } \\
\text { Tinggi }\end{array}$ \\
\hline 8 & 81 & Tinggi & 83 & Tinggi & 8 & 82 & Tinggi & 82 & Tinggi \\
\hline
\end{tabular}

Puspita Dewi ${ }^{1}$, Supardi ${ }^{2}$, dan Gregorius Rahastono Ajie ${ }^{3}$

Bimbingan dan Konseling

Universitas PGRI Semarang 


\begin{tabular}{|c|c|c|c|c|c|c|c|c|c|}
\hline \multirow{3}{*}{ No } & \multicolumn{4}{|c|}{ Pretest } & \multirow{3}{*}{ No } & \multicolumn{4}{|c|}{ Pretest } \\
\hline & \multicolumn{2}{|c|}{ Kontrol } & \multicolumn{2}{|c|}{ Eksperimen } & & \multicolumn{2}{|c|}{ Kontrol } & \multicolumn{2}{|c|}{ Eksperimen } \\
\hline & Skor & Ket & Skor & Ket & & Skor & Ket & Skor & Ket \\
\hline 9 & 83 & Tinggi & 85 & Tinggi & 9 & 94 & Tinggi & 89 & Tinggi \\
\hline 10 & 84 & Tinggi & 86 & Tinggi & 10 & 65 & Rendah & 88 & Tinggi \\
\hline \multicolumn{2}{|c|}{ Jumlah } & 802 & & 799 & \multicolumn{2}{|c|}{ Jumlah } & 818 & & 923 \\
\hline \multicolumn{2}{|c|}{$\begin{array}{c}\text { Skor } \\
\text { Tertinggi }\end{array}$} & 84 & & 86 & \multicolumn{2}{|c|}{$\begin{array}{c}\text { Skor } \\
\text { Tertinggi }\end{array}$} & 94 & & 113 \\
\hline \multicolumn{2}{|c|}{$\begin{array}{c}\text { Skor } \\
\text { Terendah }\end{array}$} & 74 & & 74 & \multicolumn{2}{|c|}{$\begin{array}{c}\text { Skor } \\
\text { Terendah }\end{array}$} & 65 & & 82 \\
\hline \multicolumn{2}{|c|}{ Rata-rata } & 80,2 & & 79,9 & \multicolumn{2}{|c|}{ Rata-rata } & 81,8 & & 92,3 \\
\hline
\end{tabular}

Grafik 1

\section{Persentase Hasil Pretest dan Posttest} Kelompok Kontrol

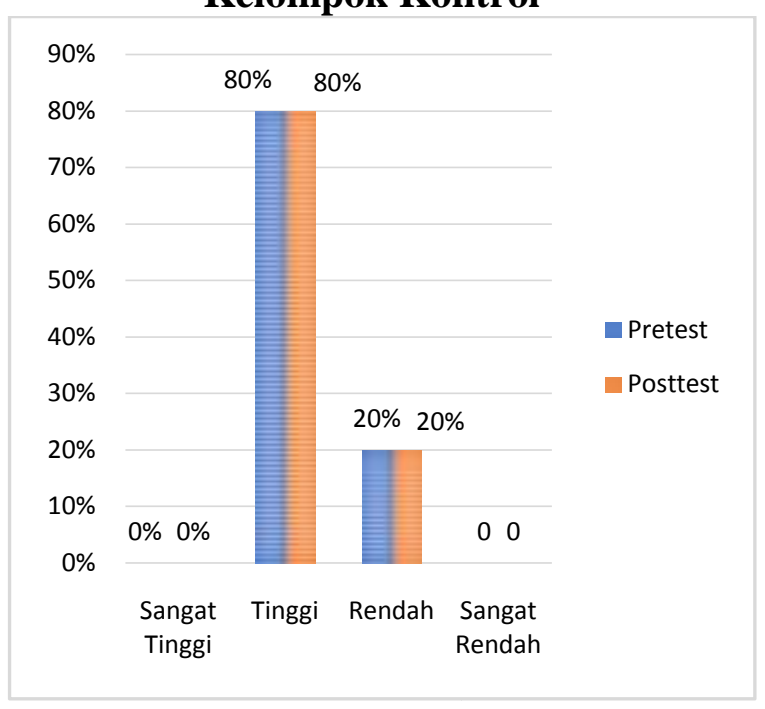

Tabel 3 Tabel Persiapan Uji Hipotesis (t-test) Data Posttest

\begin{tabular}{|c|c|c|c|c|}
\hline Subjek & $\begin{array}{c}\mathrm{X}_{1 \text { (Eks }} \\
\text { ) }\end{array}$ & $\begin{array}{c}\mathrm{X}_{2 \text { (Kontrol }} \\
\text { ) }\end{array}$ & $\mathrm{X}_{1}{ }^{2}$ & $\mathrm{X}_{2}{ }^{2}$ \\
\hline 1 & 113 & 80 & $\begin{array}{c}1276 \\
9\end{array}$ & 6400 \\
\hline 2 & 96 & 78 & 9216 & 6084 \\
\hline 3 & 83 & 87 & 6889 & 7569 \\
\hline 4 & 89 & 86 & 7921 & 7396 \\
\hline 5 & 91 & 85 & 8281 & 7225 \\
\hline 6 & 87 & 77 & 7569 & 5929 \\
\hline 7 & 105 & 84 & $\begin{array}{c}1102 \\
5\end{array}$ & 7056 \\
\hline 8 & 82 & 82 & 6724 & 6724 \\
\hline
\end{tabular}

Grafik 2

Persentase Hasil Pretest dan Posttest Kelompok Eksperimen

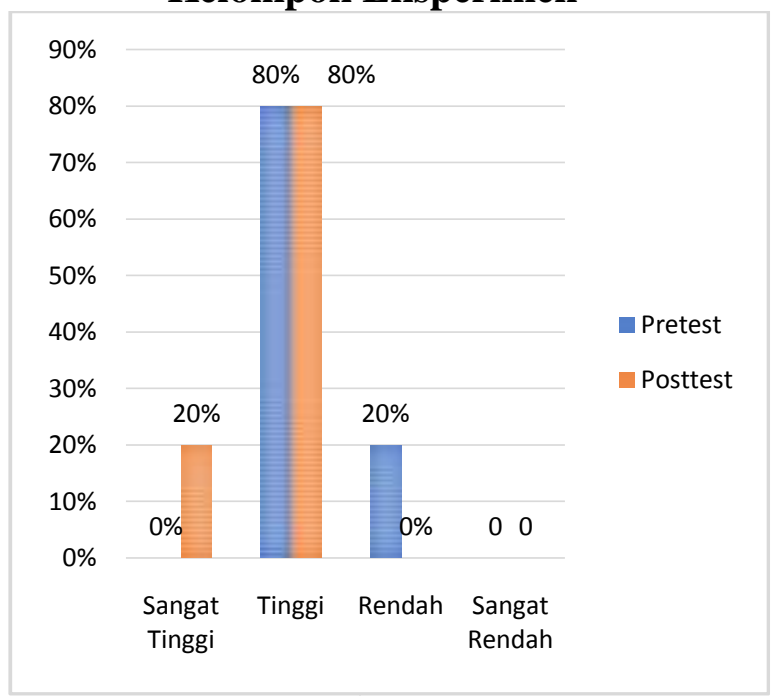

\begin{tabular}{|c|c|c|c|c|}
\cline { 3 - 3 } 9 & 89 & 94 & 7921 & 8836 \\
\hline 10 & 88 & 65 & 7744 & 4225 \\
\hline $\begin{array}{c}\text { Jumla } \\
\text { h }\end{array}$ & 923 & 818 & $\begin{array}{c}8605 \\
9\end{array}$ & $\begin{array}{c}6744 \\
4\end{array}$ \\
\hline
\end{tabular}

Perhitungan untuk uji hipotesis sebagai berikut :

$$
\begin{aligned}
& \mathrm{S}_{1^{2}}=\frac{\sum \mathrm{X}_{1}^{2}-\frac{\left(\Sigma \mathrm{X}_{1}^{-2}\right.}{\mathrm{N}}}{\mathrm{N}-1} \\
& \mathrm{~S}_{1^{2}}=\frac{86059-\frac{(923)^{2}}{10}}{10-1} \\
& \mathrm{~S}_{1^{2}}=\frac{86059-85192,9}{10-1} \\
& \mathrm{~S}_{12}=\frac{866,1}{9}=96,23
\end{aligned}
$$

Puspita Dewi ${ }^{1}$, Supardi ${ }^{2}$, dan Gregorius Rahastono Ajie ${ }^{3}$ Bimbingan dan Konseling 


$$
\begin{aligned}
& \mathrm{S}_{2}=\frac{\sum X_{2}^{2}-\frac{\left(\Sigma X_{2 i}^{7}\right.}{N}}{N-1} \\
& \mathrm{~S}_{2}=\frac{67444-\frac{818^{2}}{10}}{10-1} \\
& \mathrm{~S}_{2}=\frac{67444-66912,4}{9} \\
& \mathrm{~S}_{2}=\frac{531,6}{9}=59,06 \\
& \operatorname{sgab}=\sqrt{\frac{\left(\mathrm{n}_{1}-1\right) \mathrm{S}_{1}^{2}+\left(\mathrm{n}_{2}-1\right) \mathrm{S}_{2}^{2}}{\left(\mathrm{n}_{1}+\mathrm{n}_{2}\right)-2}} \\
& \operatorname{sgab}=\sqrt{\frac{(10-1) 96,23+(10-1) 59,06}{(10+10)-2}} \\
& \operatorname{sgab}=\sqrt{77,645}=8,811 \\
& t=\frac{\overline{\mathrm{X}}_{1}-\overline{\mathrm{X}}_{2}}{\operatorname{sgab} \sqrt{\frac{1}{\mathrm{n}_{1}+\frac{1}{\mathrm{n}_{2}}}}} \\
& t=\frac{92,3-81,8}{8,881 \sqrt{\frac{1}{10}+\frac{1}{10}}} \\
& t=2,645
\end{aligned}
$$

Setelah mengetahui perhitungan analisis uji $t$ hasil posttest pada kelompok eksperimen dan kelompok kontrol, diketahui tabel $\mathrm{db}=\left(\mathrm{N}_{1}+\mathrm{N}_{2}\right)-2=$ $(10+10)-2=18$ dengan taraf signifikan $5 \%$ yaitu $t_{\text {tabel }}=2,101$. Berdasarkan perhitungan $\mathrm{di}$ atas diperoleh $\mathrm{t}_{\text {hitung }}=$ 2,645 dimana nilai tersebut lebih besar dari $\mathrm{t}_{\text {tabel }}=2,101$. Dengan demikian dapat ditarik kesimpulan bahwa uji hipotesis $t_{\text {hitung }}>t_{\text {tabel }}$, maka Ho ditolak dan $\mathrm{Ha}$ diterima. Oleh karena itu hipotesisnya berbunyi bahwa ada pengaruh layanan bimbingan kelompok teknik symbolic modelling terhadap motivasi belajar siswa kelas XI SMA Negeri 5 Semarang.

\section{PEMBAHASAN}

Berdasarkan perhitungan uji hipotesis diperoleh $t_{\text {hitung }}=2,645$. Selanjutnya dikonsultasikan dengan $\mathrm{dk}=$ 18 dan taraf signifikansi 5\% diketahui $t_{\text {tabel }}$ $=2,101$ sehingga $\mathrm{t}_{\text {hitung }}>\mathrm{t}_{\text {tabel }}, 2,645>$
2,101. Dengan demikian Ho ditolak dan Ha diterima. Oleh karena itu hipotesis yang berbunyi "ada pengaruh layanan bimbingan kelompok teknik symbolic modelling terhadap motivasi belajar siswa kelas XI SMA Negeri 5 Semarang" diterima kebenarannya.

Analisis hasil pretest antara kelompok eksperimen dan kelompok kontrol menunjukkan bahwa tidak ada perbedaan yang signifikansi antara kelompok kontrol dan kelompok eksperimen. Rata-rata motivasi belajar kelompok kontrol dari 80,2 menjadi 81,8 terjadi peningkatan sebesar 1,6. Pada kelompok eksperimen, rata-rata motivasi belajar siswa sebesar 79,9 menjadi 92,3 terjadi peningkatan 12,4. Selisih antara kelompok kontrol dan kelompok eksperimen yaitu 10,5. Hasil analisis data menunjukkan bahwa ada perbedaan motivasi belajar antara kelompok eksperimen yang diberikan treatment berupa layanan bimbingan kelompok dengan menggunakan teknik symbolic modeling, sedangkan kelompok kontrol tidak diberikan treatment.

Penelitian ini membahas mengenai motivasi belajar siswa kelas XI SMA Negeri 5 Semarang. Siswa kesulitan menumbuhkan semangat belajar yang ditandai dengan sering keluar masuk kelas ketika jam pelajaran, terlambat masuk sekolah/kelas, menunda-nunda tugas, asik bermain gadget, asik mengobrol dengan teman ketika guru mapel menerangkan materi pelajaran, sering melamun saat diterangkan materi pelajaran. Untuk mengatasi permasalahan motivasi belajar siswa maka digunakan layanan bimbingan kelompok dengan teknik symbolic modeling. Menurut Achmad (dalam Tatoe

Puspita Dewi ${ }^{1}$, Supardi ${ }^{2}$, dan Gregorius Rahastono Ajie ${ }^{3}$ 
2017:69) layanan bimbingan kelompok yang merupakan bantuan terhadap individu yang digunakan dalam situasi kelompok. Layanan bimbingan kelompok digunakan sebagai media membimbing individu untuk mencapai tujuan bersama dengan memanfaatkan dinamika kelompok. Adapun teknik symbolic modeling merupakan cara/prosedur yang dilakukan dengan menggunakan media seperti film, video, buku pedoman, dll dengan cara mendemonstrasikan perilaku yang dikehendaki atau hendaknya dimiliki oleh klien (Ratna, 2013:52).

Berdasarkan uraian di atas dapat dikatakan bahwa bimbingan kelompok dengan teknik symbolic modeling dapat meningkatkan motivasi belajar siswa kelas XI SMA Negeri 5 Semarang. Layanan bimbingan kelompok yang diberikan pada kelas XI IPA 9 atau kelompok eksperimen dengan menggunakan teknik simbolic modeling dapat mendorong siswa mengembangkan perasaan, pikiran, persepsi, wawasan dan sikap yang menunjang peningkatan motivasi belajar siswa. Hal tersebut disampaikan oleh Tohirin (2015: 165) yang menyatakan bahwa secara umum layanan bimbingan kelompok bertujuan untuk pengembangan kemampuan bersosialisasi, khususnya kemampuan berkomunikasi peserta layanan (siswa) dan secara khusus layanan bimbingan kelompok bertujuan untuk mendorong pengembangan perasaan, pikiran, persepsi, wawasan dan sikap yang menunjang perwujudan tingkat laku yang lebih efektif, yakni peningkatan kemampuan berkomunikasi siswa, baik verbal maupun non verbal. Teknik symbolic modeling membantu untuk masalah-masalah yang kognitif seperti motivasi dalam belajar. Video modeling dan video self-modeling telah digunakan dengan sukses dengan individu yang memiliki disabilitas perkembangan dan masalah externalizing (mengarah ke luar diri), seperti perilaku disruptif atau agresif (Green et al, dalam Erford, 2017:348).

\section{SIMPULAN DAN SARAN}

Berdasarkan penelitian yang sudah dilakukan, diperoleh kesimpulan sebagai berikut : Tingkat motivasi belajar siswa kelas XI SMA Negeri 5 Semarang sesudah diberikan layanan bimbingan kelompok mengalami peningkatan. Hal ini terbukti dari hasil pretest diketahui skor rata-rata motivasi belajar kelompok kontrol dari 80,2 menjadi 81,8 setelah dilakukan treatment dengan peningkatan sebesar 1,6. Pada kelompok eksperimen, rata-rata motivasi belajar siswa sebesar 79,9 menjadi 92,3 setelah dilakukan treatment dengan peningkatan 12,4. Selisih antara kelompok kontrol dan kelompok eksperimen yaitu 10,5.

Layanan bimbingan kelompok dengan teknik modeling berpengaruh terhadap motivasi belajar siswa kelas XI SMA Negeri 5 Semarang. Hal tersebut dibuktikan dengan perhitungan uji hipotesis yang diperoleh $t_{\text {hitung }}=2,645$. Selanjutnya dikonsultasikan dengan $\mathrm{dk}=$ 18 dan taraf signifikansi $5 \%$ diketahui $t_{\text {tabel }}$ $=2,101$. Nilai $t_{\text {hitung }}>t_{\text {tabel }}, 2,645>2,101$ yang artinya terdapat pengaruh layanan bimbingan kelompok teknik symbolic modelling terhadap motivasi belajar siswa kelas XI SMA Negeri 5 Semarang.

Melihat hasil penelitian, saran- saran yang diajukan peneliti adalah : Bagi siswa, setelah mendapatkan layanan bimbingan kelompok dengan teknik symbolic 
modeling diharapkan agar siswa dapat memiliki motivasi belajar yang tinggi sehingga dalam pembelajaran siswa dengan mudah menerima materi yang disampaikan. Bagi Guru BK, diharapkan dengan adanya penelitian ini guru bimbingan dan konseling mampu memberikan layanan berupa bimbingan kelompok yang dapat dilakukan pada jam sekolah maupun di luar sekolah. Dan bagi peneliti selanjutnya, diharapkan mampu mengadakan penelitian tentang motivasi belajar siswa dengan menggunakan teknik yang berbeda atau layanan yang berbeda.

\section{DAFTAR PUSTAKA}

Djamarah, Syaiful Bahri. 2015. Psikologi Belajar. Jakarta: Rineka Cipta

Erford, Bradley T. 2017. 40 Teknik yang Harus Diketahui Setiap Konselor. Edisi Kedua. Yogyakarta: Pustaka Pelajar.

Jailani, Muhammad. 2019. Hubungan Status Sosial Ekonomi Orang Tua Terhadap Motivasi Anak Untuk Berwirausaha. Pedagogik: Jurnal Pendidikan, 14(1):35-42.

Putra, Chandra Anugrah. 2016. Pengaruh Strategi Pembelajaran Berbasis Proyek Perancangan dan Kecerdasan Logik-Matematik Terhadap Kompetensi Merancang Web. Jurnal Teknologi Pendidikan, 18(2):90-101. Ratna, Lilis. 2013. Teknik-teknik Konseling. Yogyakarta: Budi Utama. Safithry, Esty Aryani \& Niky Anita. 2019.

Konseling Kelompok Dengan

Teknik Self Management Untuk

Menurunkan Prasangka Sosial

Peserta Didik. Suluh: Jurnal

Bimbingan Dan Konseling, 4(2):33-

41.
Sardiman. 2008. Interaksi dan Motivasi Belajar Mengajar. Jakarta: Raja Grafindo Persada.

Setiawan, M Andi. 2015. Model konseling kelompok dengan teknik problem solving untuk meningkatkan selfefficacy akademik siswa. Jurnal Bimbingan Konseling 4(1).

Sugiyono. 2015. Metode Penelitian Pendidikan. Bandung: Alfabeta

Sukardi, Dewa Ketut. 2008. Pengantar Pelaksanaan Program Bimbingandan Konseling di Sekolah. Jakarta: Rineka Cipta.

Supardi. 2016. Dasar-Dasar Metodologi Penelitian Bimbingan \& Konseling. Yogyakarta: ANDI Offset.

Yuniarwati, Christiyo Tri. 2018. Meningkatkan Motivasi Belajar Melalui Layanan Bimbingan Kelompok dengan Teknik Modeling pada Siswa Kelas Kelas XI APh1 SMK N I Cepu Semester Gasal Tahun 2017 / 2018. EMPATI-Jurnal Bimbingan dan Konseling Vol 5 No 1 e-ISSN : 2581-0677.

Puspita Dewi ${ }^{1}$, Supardi ${ }^{2}$, dan Gregorius Rahastono Ajie ${ }^{3}$

Bimbingan dan Konseling

Universitas PGRI Semarang 